\title{
Is Annual Style Change in the Automobile Industry an Unfair Method of Competition? A Rebuttal
}

\author{
Stephen E. Selander"
}

Two years ago, a Note in this Journal ${ }^{1}$ argued that annual style change in the automobile industry is an unfair method of competition which creates and preserves concentrated economic power. The Note is, however, based on errors severe enough to invalidate its basic thesis.

Before proceeding with a detailed analysis, one fundamental point should be considered. The Note fails to recognize that if style change is desired by consumers, this "unfair method of competition" does nothing more than answer consumer demand-something which is not, and should not be, illegal under the antitrust laws absent an intent to monopolize.

Analysis of the industry supports the view that consumers prefer annually redesigned cars. ${ }^{2}$ Lawrence White found that "the market allocation, stressing model changes, probably reflects accurately consumer preferences." 3 Indeed, the Note's theory that annual style change creates and preserves concentrated economic power rests on an implicit premise that annually redesigned cars are preferred, for if change were not desired, non-change firms would enter the industry, prosper, and expand.

Even if annual style change did have the economic impact the Note suggests, it should still be legal as a legitimate attempt to meet consumer demand. In fact, however, annual style change was not a fundamental factor in the evolution of the automobile industry.

* Third-year student, U. of Mich. Law School. M.A. Economics, U. of Mich. (1968). This project was started during a legal clerkship for General Motors in the summer of 1971.

1. Note, Annual Style Change In The Automobile Industry As An Unfair Method of Competition, 80 YaLE L.J. 567 (1971) [hereinafter cited as the Note]. Bradford C. Snell, a student editor, is listed as the contributor of the Note. 80 YALE L.J. 515.

2. According to the Note, GM, adopting a style change policy, increased its sales from thirteen to forty-three percent of the total industry sales in the five years between 1922 and 1927, while Ford's share fell from fifty-one to nine percent during this same period because of its failure to respond with style changes. Note at 579-80. These statistics overemphasize the impact of style change, since Ford's production facilities were shut down in June of 1927 in order to convert for production of the Model A. The first Model A's were not sold until December 1927. See E. KENNEDY, THE AUTOMsobile INDUSTRY 190, 199 (1941). However, it does appear that the change to the Mlodel $A$ mas a response to the declining sales of the non-style change Mfodel T between 1923 and 1926.

3. L. White, The Automoblle Industry SiNce 1945, at 210 (1971). 
I. The Early Structure of the Automobile Industry and the Advent of Style Change

The Note argues that General Motors' institution of a policy of annual style change in $1923^{4}$ caused several significant changes in the structure of the automobile industry. However, major errors in the Note's description of these changes undermine the Note's conclusions about the causes of the changes.

\section{A. Total Number of Producers}

One dimension of market structure which, according to the Note, underwent significant change in 1923 was the degree of seller concentration, that is "the number and the size distribution of sellers in the market." 5 The Note indicates that the number of firms in the automobile industry grew to a high of eighty-eight in 1921 and that "about 1923, the number of automobile producers began to decline rapidly." It then adds: "Prior to the introduction of annual style change in 1923 , entry into the automobile industry was relatively easy, exits were insubstantial in number and concentration was consequently low." Finally, the Note contends that between 1923 and 1926, forty-six firms left the industry, and that by 1935 only ten firms were still producing automobiles. ${ }^{8}$

The facts, however, do not support the theory that this decline in the number of firms resulted from the introduction of annual style change. The number of exits before 1923 was ninety-four, with an average of 6.31 exits per year between 1910 and $1922 .^{\circ}$ The average increased only slightly between 1923 and $19300^{10}$

The Note's figure of ten firms in 1935 was taken from Dr. Ruby Turner Norris' testimony on administered prices in the automobile industry. ${ }^{11} \mathrm{Dr}$. Norris traced the life span of thirty-nine firms which

4. Although, in 1923, General Motors did start introducing annual models, this was not yet a formal company policy. See A. Sloan, My Years WITH General Motors 152, 163, 165-68 (1964).

5. J. Bain, Industrial Organization 7 (2d ed. 1968).

6. Note at 577 .

7. Id. at 578 .

8. Id.

9. R. Epstein, The Automobile Industry, Its Economic And Commercisl DeveloyMENT 176 (1928). It should be noted that Epstein defines "exit" to include dropping " make of automobile, even if the company continues in business. $I d$. at 165.68. This defi nition does not have the normal economic significance associated with the word "cxit." It also makes comparability of exit statistics difficult.

10. Auromotive News, 1970 Almanac $40-41$ (1970). Although comparability is difficult, this author believes the average number of exits increased to about 8.0 per yeir.

11. SUbCOMM. ON ANTITRUST \& MONOPOLY OF THE SENATE COMM. ON TIIE JUdiciakx, 85th Cong. 2d Sess., Study of AdMinistered Prices in the AUTOMOBILE INdustky 9 (1958) [hereinafter cited as ADMINISTERED PRICES]. 
she considered to be most of the principal producers in the history of the industry. Of the thirty-nine, only twenty-four were producing at the beginning of 1923 when style change started. Between 1923 and 1929, the number of firms declined by nine: four through merger, ${ }^{12}$ five through failure. ${ }^{13}$ of the latter five, the largest, Chandler, accounted for only 20,268 new car registrations in its best year ${ }^{14}$ approximately forty percent of the minimum efficient scale which the Note later argues a non-style change producer needs. ${ }^{15}$ Thus, it would appear annual style change played little if any role in the decline in numbers between 1923 and 1929 .

Five more companies failed between 1930 and 1935, leaving only ten in the industry. ${ }^{16}$ Again, none of these five was near the minimum efficient level for a non-style change producer; the biggest fell short by forty percent in its largest production year. ${ }^{17}$ Obviously, the Depression was a major factor in the elimination of these lower volume car producers. ${ }^{18}$

While there was thus no significant change in the number of exits associated with annual style change, there was a noticeable decline in the number of new firms entering the industry. It is not, of course, possible to know precisely who considered entering the industry, or their reasons for failing to do so. However, reasons can be postulated for the decline in the rate of entry after about 1920 that seem at least as plausible as annual style change.

First, the rate of growth of demand declined. The automobile industry moved from an era of rapidly rising demand, when consumers were switching from other modes of transportation to the auto, to a situation where demand was relatively constant. ${ }^{10}$

[Before 1922] [A]ny ambitious manufacturer . . . who could get hold of some capital and some engineering brains and could make a fairly good product, could come in and take a slice of the middle,

12. Chalmers merged with Maxwell, Lafajette with Nash, Picrec-Arrow with Studebaker, and Dodge with Chrysler. See id. at chart facing 9.

13. Stearns Knight, Locomobile, Peerless, Mroon and Chandler failed. See id.

14. Automotive News, supra note 10 , at 40 .

15. The Note at 581 indicates the minimum efficient scale is 50,000 units for an automobile assembler.

16. Franklin, Auburn, Reo, Nordyhe-Marmon, and Kissel failed between 1930 and

1935. AdMINISTERed Prices, supra note 11, at chart facing 9.

17. AUtomotive News, supra note 10 , at 40.

18. See Administered Prices, supra note 11 , at 9.

19. Epstein found that in the 1920's and 1930's there was no general increase in automobile production. See Trial Transcript, at 1755, Winkelman v. General Motors Corp., 44 F. Supp. 960 (S.D.N.Y. 1942). United States production of automobiles in 1923 was $4,034,012$, while in 1928, it was 4,358,748. NAt'L Automodile Cinssabs of Cossirnce, Facts \& Figures of the Automobile INdustry 19 (1930). 
the lower-middle, or the upper-middle car market. But after 1922 . 1923, because of what had come into the total picture-this stabilized total demand-it took a very different kind of brains and imagination and management quality to make a success in the automobile industry, because the total demand had ceased to grow, and if any producer wanted to increase his sales, he had to take it out of somebody else's share, and that meant real competition. ${ }^{20}$

Moreover, the character of demand changed in the 1920's from an initial to a replacement demand. ${ }^{21}$ Many purchasers were now repeating buyers of the same make that they had originally owned. Many preferred to purchase from companies whose products were known for their dependability, rather than to gamble on a new firm. It would not be surprising, therefore, if this change in demand also discouraged new entry. In fact, the few new entrants in the industry during the 1920 's were individuals who had made names for themselves with other automobile companies. ${ }^{22}$

Second, a major change in body production occurred during the 1920 's. In 1919, only 10.3 percent of the bodies produced were closed; by 1926 , this had increased to seventy-four percent. ${ }^{23}$ The change from open, wooden bodies to closed, steel ones increased the minimum efficient scale of body production. ${ }^{24}$ This would appear to be another strong explanation for a decline in entry.

Finally, the 1920's brought the installment purchase, with trade-ins as down payment. This caused the used car to become a significant component of supply. ${ }^{25}$ Thus, a new entrant had to compete not only with new car manufacturers, but also with the used car salesmen.

\section{B. Concentration of Sellers}

The Note also asserts that annual style change increased the concentration of sellers. It states that "not until the 1920's did the three lead-

20. Trial Transcript, at 1759, Winkelman v. General Motors Corp., 44 F. Supp. 960 (S.D.N.Y. 1942).

21. Between 1923 and 1928, the percentage of American purchases going to new or multiple car buyers fell from 69.9 percent to 27.4 percent. The purchases represcnting replacements of old cars rose from twenty-one percent to 54.6 percent during the same period. FACTS AND Figures, supra note 19, at 14 .

22. William Durant started four new firms in 1922. Walter Flanders and B.F. Everitt were principals in the Rickenbacker Motor Car Company. Walter Chrysler started Chrys. ler. All of these men were experienced men who had been in the auto industry for several years. Frank L. Klingensmith, a Ford Treasurer and General Manager, started Gray Motor Company.

23. See Stillman, Another Record-Breaking Year, 56 Automotive Industkies 227, 220 (1927).

24. See Schipper, Improved But Cheaper Closed Bodies Are Predicled, 47 AUtomorivr: INDUSTRIES 127 (1922).

25. See SloAN, supra note 4 , at 282. 
ing firms in the auto industry account for much more than half of total sales." 26 Later, it contends that "[w] hile aggressively pursuing annual style change, GM, Chrysler, and Ford increased their collective share of industry sales from less than 65 percent in 1923 to more than 90 percent by 1935."27

From the Note's own statistics on concentration, however, it would appear that the three largest firms increased sales from about fifty percent to sixty-five percent while pursuing a non-style change policy between 1920 and 1923. From 1923 to 1928 (years with style change), concentration increased only four percentage points, from sixty-five to sixty-nine percent. ${ }^{28}$ From 1929 to 1935 concentration increased from seventy to ninety percent. But in this latter period, the Depression was surely a major factor. It is thus difficult to attribute the overall increase in concentration between 1923 and 1935 to annual style change.

Moreover, the Note's statistical assertions are at the least misleading. The FTC report cited indicates that the two leading firms had more than fifty percent of sales from 1913 on. The concentration for two firms in 1919 was 60.85 percent, increasing to 68.41 percent by 1921.23 This was, of course, due to Ford's large share of the market, but it does indicate that substantial concentration existed in the industry before the advent of annual style change.

Data supplied by other economists also cast doubt on the Note's view of concentration. According to Weiss, when Chrysler's predecessor, Dodge, is included, the Big Three accounted for nearly eighty percent of the market in $1921 .^{30}$ From 1923 to 1929 , the concentration ratio was below the 1921 figure, with the share of the smaller firms increasing slightly, although in an erratic manner. Thus, Weiss' analysis also indicates that the Note is wrong about pre-style change concentration and raises serious doubt as to whether style change caused any significant increase in concentration.

\section{Concentration and Style Change-The Economic Analysis}

The Note argues that annual style change led to and preserved concentration in the industry. According to the Note, components integration, franchised distribution, large-scale advertising, and heavy capi-

26. Note at 579 .

27. Id. at 580 .

28. Id. at 571 n.21.

29. Compare id. at 579 n.60 with Federat Trade COMM'N, Rerort on tue Motor VEHICLE INDUSTRX 29 (1939).

30. See L. Weiss, Economics AND AMERICAN INDUSTRY 327 (1967). 
tal requirements for new entry are derivatives of the style-change strategy. ${ }^{31}$ In addition, the Note claims, style change forces small firms to suffer the cost of "premature" scrapping of tools and dies, thus squeezing small assembly firms out of the industry. ${ }^{32}$

Contrary to the Note's analysis, however, annual style change played an insignificant role in the evolution of the automobile industry. There are sound economic causes for the industry's structure which have little or nothing to do with style change.

\section{A. Style Change and Vertical Integration}

\section{Upstream Integration into Components Production}

The Note suggests that annual style change led to integration of car assembly and components production.

An inevitable result of the drive to produce "all new" cars an. nually was an industry trend toward components integration. Previously, producers had attained optimal efficiency at low output volumes by assembling basically interchangeable body and engine components purchased from external suppliers. ${ }^{33}$

The Note, however, fails to point out that "previously" refers-in the sources cited-to the period between 1902 and $1909 .{ }^{.34}$ Weiss presents a far clearer picture of the timing and levels of vertical integration:

As they accumulated capital, the larger auto makers began producing some of the components for their cars. By the start of World War I, practically all of the firms of lasting importance were producing at least their own motors, so that they could plausibly claim distinct and superior products. During the shortages of World War I, the drive of manufacturers to produce their own supplies was accelerated. Ford seems to have become obsessed with selfsufficiency. . . Capital requirements in the beginning had been little more than an investment in parts and payroll while cars were in process, but any new automobile producer from World War I on had to invest millions in plant and equipment, as well. ${ }^{35}$

31. Note at $\mathbf{5 7 7 .}$

32. Id. at 608 .

39. Id. at 580 .

34. See id. at 580 n.70. Vatter, The Closure of Entry in the American Automobile Industry, 4 OXFORD ECON. PAPERs 213 (1952) refers to the 1905 description of the industry at 216.17. Lanzillotti, The Automobile Industry, in W. AdAMs, THE STRUCTURE OF AMER1CAN INDUSTRY 314 (1961), describes the period between 1902 and 1909.

35. Weiss, supra note 30, at 331-32. See also J. RAE, The American Automonile, A Brief History 96 (1965). 
Thus, components integration was a substantial factor in the automobile industry long before annual style change.

Economists would predict vertical integration whenever the costs of outside market transactions are greater than the costs of accomplishing the same results within the firm. Bain notes some of the economies to be derived from integrating the production of components with their assembly:

[E]conomies are usually attributed to improved coordination of the rates of output at the successive stages (through placing them under one management), consequent reduction of intermediate inventories, and elimination of the expense of purchase-sale transactions in moving goods from one stage to the next. 30

The complex nature of automobiles also increases the desirability of vertical integration. White states:

The advantages of unified coordination and control extend beyond just one plant. The complex process of designing, producing, testing, and modifying an automobile requires a high degree of coordination. Engine transmission, frame, body, brakes, windshield, and other components all have to perform well with each other and have to be in the right place at the right time and in the right quantities. A failure in the supply of any component can spell disaster. ${ }^{37}$

Thus, it is not surprising that the automobile industry moved towards vertical integration, even before annual style change.

Another factor evidently leading to vertical integration is product differentiation, which as the Note indicates ${ }^{38}$ has served as a key element in competition since the industry's beginnings. To the extent that the components of the product are unique and require non-standardized design, "close control and perhaps secrecy will be required to design, develop, and coordinate these components."30 Annual style change would make coordination more important in the automobile industry, but it is still only one factor leading an automobile firm to recognize the efficiencies attained by the vertical integration of components production.

36. BaIN, supra note 5, at 177-78.

37. Whrte, supra note 3 , at 78 .

38. See Note at 579.

39. WhrTe, supra note 3 , at 78. 


\section{Downstream Integration into Distribution}

The Note also argues that annual style change required the automo. bile firms to integrate distribution and car assembly activities:

[T] he need to differentiate the appearance of automobiles annually and the consequent decline in the interchangeability of components required the establishment of unique nationwide service organizations. ${ }^{40}$

This allegedly placed small firms at a disadvantage because of the capital required for, and the economies of scale associated with, a nationwide dealer system. Again, however, factors other than annual style change can better explain the emergence of nationwide service organizations.

Indeed, the dealer system began before the introduction of annual style change. Lanzillotti indicates that about 1910 "[a] large number of well-financed dealers across the country was recognized as essential for survival . . ."41 Between 1910 and 1920, the dealer system grew from 8,402 to 30,771 dealers. ${ }^{42}$ Ford alone had 7,000 dealers in $1913^{43}$ and 17,000 by 1921,44 two years before the introduction of annual style change.

As the automobile became an established method of transportation and the nation developed its highway network, consumers became unwilling to buy a new car without an assurance of reliable service wherever they traveled. Because of product differentiation, a service center might need special equipment for diagnosing the problems of a particular car. Similarly, product differentiation meant that there were differences in components between the various makes. Such factors suggest that it would be desirable to have a service center specialize in only a few makes of cars.

Moreover, adequate nationwide service obviously requires several thousand dealers. The Note is correct in stating that the scale for efficient distribution is far larger than the scale for efficient assembly. ${ }^{40}$ However, it is not at all clear that elimination of annual style change would significantly reduce the efficient scale for distribution. Nor is it clear that the establishment-for whatever reasons-of a nationwide

40. Note at 584 .

41. Lanzillotti, supra note 34 , at 315 .

42. FACTS AND FIGURES, supra note 19, at 42.

43. RAE, supra note 35 , at 61 .

44. Id. at 82 .

45. See B. Pashigian, The Distribution of Automobites, An Economic Analysis of THE FRANCHISE SYSTEM 238-39 (1961). 


\section{A Rebuttal}

dealer system called for tremendous capital by small automobile producers. In general, capital for these dealerships comes from sources other than the automobile manufacturers. ${ }^{40}$ The auto maker occasionally provides some financial protection for the dealer on his inventory of spare parts, but the normal procedure is for the dealer to finance his own inventory. It was such independent financing which made the dealer system attractive to manufacturers in the early days of the industry. ${ }^{47}$ There is no evidence, therefore, that the establishment of nationwide service systems placed unreasonable capital requirements on small manufacturers.

\section{B. The "Premature" Scrapping of Tools and Dies}

The Note also argues that annual style change significantly raised the costs of small firms by necessitating "premature" scrappage of tools and dies and increased the scale necessary for survival in the industry. ${ }^{48}$ These disadvantages allegedly caused small firms to fail, and discouraged new ones from entering. There are, however, several errors in this analysis which may invalidate its conclusions.

In Figure I of the Note, ${ }^{49}$ reproduced here, a hypothetical small assembly firm, $X$, is compared with GM, a large firm integrated upstream into components manufacture. The Note assumes that, without style change (in 1923), both firms face the same average costs (per car produced), AC. Producing at 50,000 cars a year, $X$ has just "achieved the minimum level of output for optimally efficient assembly operntions" ${ }^{\prime \prime 0}$ (i.e., the smallest output at which the lowest costs per unit

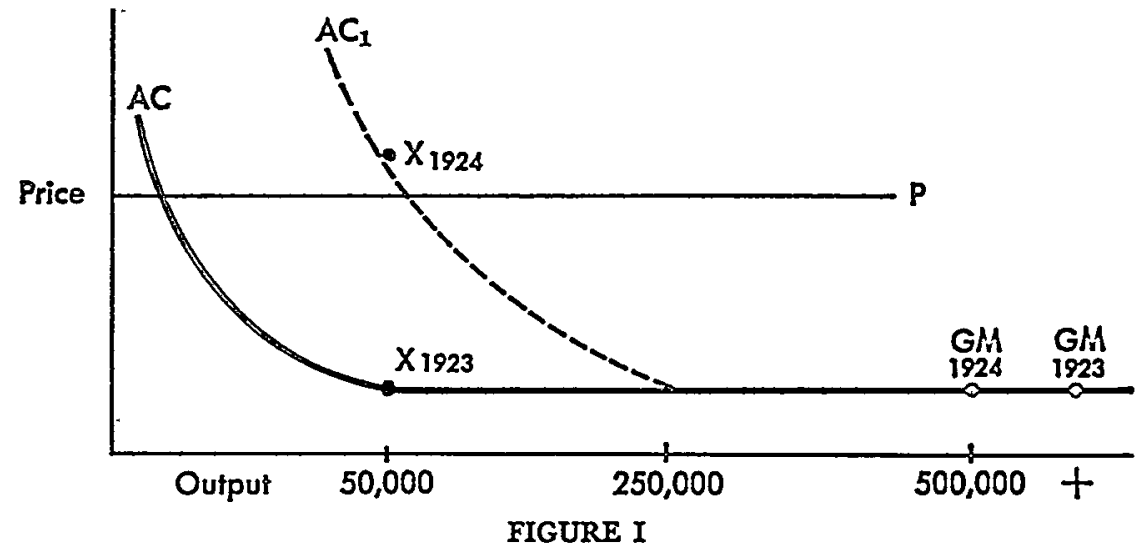

46. See Administered Prices, supra note 11, at 16 n.28.

47. See RAE, supra note 35, at 18-19, 81-82.

48. Note at 580-83.

49. Id. at 581 .

50. Id. 
can be achieved). But style change (in 1924) allegedly raises the relevant cost curve to $A C_{1}$, which exceeds $A C$ for all production volumes of less than 250,000 cars per year. In explaining this increase, the Note observes that style change forces the small firm to purchase "the expensive tools and dies necessary for the integrated production of uniquely styled vehicles," ${ }^{51}$ and that-because these tools and dies do not "physically deteriorate" until they have produced 250,000 carsannual style change forces a small firm to scrap dies and tools "prematurely." Since physical deterioration would dictate annual die scrap. page in a firm producing 250,000 units even if style change were not practiced, the introduction of style change does not alter the average costs of this firm. The Note concludes that "[a]fter 1923 . . . survival as a style change manufacturer required construction of a plant capable of producing at least 250,000 automobiles per year from internally manufactured and annually altered components." 52

This analysis is seriously misleading. It attributes to style change cost differentials between large and small firms caused in large part by economies of scale which exist whether or not style change is practiced; the analysis also confuses the concepts of survival and of minimum efficient size.

First, the curve $\mathrm{AC}_{1}$ includes total tooling costs on a per car basis, ${ }^{63}$ while curve AC includes no tooling costs at all. Even if style change is not practiced, an unintegrated assembly firm purchasing metal bodies from an independent supplier will have to cover the supplier's tooling costs; the supplier cannot, after all, operate at a loss. It is absurd to compare the average costs of "production" without tooling costs to the average costs including tooling and then to attribute the difference to style change. ${ }^{54}$ As argued above, style change is not the cause of vertical integration in the industry. ${ }^{55}$ And even if it were, integration could not rationally be viewed as the source of components costs; an

\footnotetext{
51. Id. at 582 .

52. Id.

53. Although the Note never explicitly states that AC excludes tooling costs, the Note at $581 \mathrm{n.74}$ indicates that its graphical analysis follows Menge. The Menge analysis uses an average cost curve with no toolings costs as its starting point. See Menge, Slyle Change Costs as a Market Weapon, 76 Q.J. OF EcoN. 632, 634-43 (1962).

54. When tooling costs are included the firm with the lower rate of output will have higher per unit costs irrespective of style change. Annual style change may increase thesc costs even more because of additional tooling expenditures. However, if non-style change cars are not desired, it makes no sense to talk about an "efficient" non-style changc pro. ducer, because the price consumers are willing to pay will be less than the costs. (Other. wise, the non-style change producer would be able to compete effectively in the market.) If price is less than costs, for the non-style change producer, resources should be allocatcd away from producing the non-style change car.

55. See pp. 696-99 supra.
} 


\section{A Rebuttal}

unintegrated assembly firm pays such costs whenever it purchases components from suppliers.

Second, by showing $\mathrm{X}$ and GM at the same average cost level along curve $A C$, the Note ignores the fact that the larger firm will enjoy scale economies in the components industry unavailable to the smaller.50 Although at 50,000 cars per year, $\mathrm{X}$ may have achieved minimum average costs in assembly operations, it will have to pay more for components than will the large firm. ${ }^{57}$ Discussing such economies, Scherer states:

Special machines can be designed to perform certain tasks at a considerable savings of time and labor. But the small scale producer may find no advantage in adopting them, because they cannot be scaled down and would therefore be idle much of the time leaving a small number of units of output to bear the full burden of their capital costs. For instance, a large automobile engine plant can save millions of dollars annually by investing in automated cylinder boring, valve seating, and work piece transfer machines, while the low volume producer must opt for slower, more labor intensive, general purpose machine tools. 58

Examination of components production suggests that there are economies of scale directly associated with efficient die utilization. According to the Note, dies are capable of producing 250,000 units a year.50 If this is true, the assembler needing only 50,000 units utilizes the dies only twenty percent of the time, allowing them to stand idle eighty percent of the time. There will be higher overhead costs for such a smaller firm (or its components supplier), because of the space required to house the idle dies. Furthermore, dies are used in presses to stamp out the metal parts of components-presses also capable of producing far more than 50,000 units per year. Although a firm may fully utilize its presses by producing several different components, additional time and costs are involved in setting up and taking down these presses for several shorter production runs.

56. See J. BaIN, Barriers to New CoMpermon 245-47 (1956) indicates cconomies of scale in body production from 300,000 to 600,000 units); WHITE, supra note 3 , at 38 (indicates that the largest economies in body production occur at 400,000 units).

57. Of course if there were no product differentiation, several small assemblers could buy standardized components from a supplicr capable of achicving economies of scale in components production. But it is unrealistic to exclude product differentiation, and impermissible to attribute to style change the effects of that artificial exclusion.

58. F. Scherer, Industrlal MAarket Structure and Economic Perforarance 73 (1970).

59. The Note may imply dies are capable of producing 250,000 units per one-third year, since GM produced 775,000 automobiles in 1923, and, according to the Note, exhausted three sets of dies. Note at 581 . The point made in the text above does not, however, turn on any particular set of numbers. 
Thus the "premature scrappage" argument itself suggests that-regardless of premature scrappage and style change-the small firm will have higher average costs than the large firm. Assume that there is no style change and that a die can be purchased for $\mathrm{C}$ dollars. The large firm must purchase a die every year, so that its average cost will be G/250,000. The small firm uses one die for five years. The Note implicitly assumes that these costs can be spread over five years, so that annual average costs for the small firm would equal those for the large firm: $1 / 5$ times $C / 50,000$ equals $C / 250,000$. But this ignores the fact that the small firm has tied up $C$ dollars for five years, and that this is costly-a cost expressed by the interest rate on loans. A large firm escapes such "time charges," thus enjoying an important economy of scale.

A second error in the Note's analysis of "premature scrappage" is the assumption that conclusions about a firm's "survival" may be derived from discussions about minimum efficient firm size. Whenever the price of a firm's product equals or exceeds average cost, the firm will be making a profit and will be able to survive. Thus, a firm need not attain minimum average cost to survive. Survival depends on the relationship of price to average cost. The Note correctly observes that premature scrapping will, other things being equal, increase the average costs of any firm producing less than 250,000 cars a year. But the amount of this increase is not stated; nor is any procedure advanced for measuring it. And the relationship of price to average costs, which is crucial for the question of survival, receives no attention. We are, of course, given a diagram. But, on it, curve $A_{1}$ implies that the breakeven or survival volume of a firm under style change (i.e., the point where price equals average cost) is only 60,000-units-per-year, which does not seem prohibitively large. In short, the Note's diagram and discussion provide no basis for its conclusion that style change established a production requirement of 250,000 units per year for survival.

\section{C. "Massive" Advertising and Annual Style Change}

The Note suggests that the policy of annual style change was responsible for massive advertising. It argues that when the designs of automobiles remain basically unchanged for a substantial period of time, the public becomes familiar with them and there is little need to "repeatedly call the public's attention to the outstanding features of unchanged models." 60

60. Note at 578 n.56. 
In 1967-68, advertising as a percentage of sales for various industries was as follows: ${ }^{\text {e1 }}$

$\begin{array}{lc}\text { Soap and Related Products } & 10.89 \% \\ \text { Bottled Soft Drinks, Flavorings } & 6.37 \\ \text { Tobacco } & 6.04 \\ \text { Chemicals, Allied Products } & 4.23 \\ \text { Food and Kindred Products } & 2.52 \\ \text { Household Appliances } & 2.42 \\ \text { MOTOR VEHICLES } & 1.14 \\ \text { All Manufacturing } & 1.44 \\ \text { All Industrial Groups } & 1.17\end{array}$

It should be noted that advertising expenditures are high in some industries which sell differentiated products but where there is no appreciable style change. This would suggest that although the public is familiar-with the product, there is still the need to "repeatedly call the public's attention to the outstanding features of unchanged models."

White found that advertising averages about $\$ 65$ per car, $\$ 40$ spent by the manufacturer and $\$ 25$ by the dealer. ${ }^{62}$ The Note gives no indication as to the proportion of this figure which can be associated with style change. ${ }^{63}$ One study found that between 1956 and 1960 only $\$ 14$ in advertising expenses was due to style change. ${ }^{\text {ot }}$

\section{Annual Style Change and Increased Capital Requirements}

A final factor which the Note examines is the increase in capital requirements allegedly caused by annual style change. The Note reasons that annual style change increased the capital requirements of firms because "each of the three factors necessary for annual style change involved tremendous capital investments of hundreds of millions of dollars." ${ }^{65}$ But, as argued above, ${ }^{06}$ annual style change was not a sig-

61. Percentage of Sales Invested in Advertising in 1967-69, Advertnsing AgE, January 25, 1971, at 77.

62. WHITE, supta note 3 , at 224.

63. Volkswagen spent $\$ 44$ per car in the United States in 1967. Wurre, supre note 3 , at 334 n.13. However the Note might argue that Volkswagen would have spent less, if there was no necessity to compete in a style change market.

64. Fisher, Griliches \&: Kaysen, The Costs of Automobile Mlodel Changes Since 1989, $70 \mathrm{~J}$. POL. ECON. 433, 437 (1962).

65. Note at 584 .

66. See pp. 696-702 supra. 
nificant cause of components integration, "massive" advertising, or the dealer franchise system.

The Note also argues that capital required for style change has preserved concentration:

In 1970 , it would cost a company $\$ 779$ million to enter the automobile industry. The costs of annual style change capability, it is estimated, account for fully $\$ 724$ million, or more than 90 percent of this figure. ${ }^{07}$

But the Note misrepresents what the figures actually show. They merely compare the capital required by an automobile assembler with the capital required by a fully-integrated manufacturer. To attribute to style change all of the differences between mere assembly and full integration is totally unrealistic. Nevertheless, it is instructive to examine the Note's estimate. ${ }^{68}$

\begin{tabular}{|c|c|c|}
\hline & Caaprtal 1 & quired \\
\hline Activity & $\begin{array}{l}\text { Integrated } \\
\text { Producer Output } \\
300,000 \text { Units }\end{array}$ & $\begin{array}{l}\text { Assembler } \\
\text { Output } \\
\text { 60,000 Units }\end{array}$ \\
\hline $\begin{array}{l}\text { Production } \\
\text { Distribution } \\
\text { Advertising } \\
\text { Retooling }\end{array}$ & $\begin{aligned} \$ 250 \mathrm{M} \\
326 \mathrm{M} \\
23 \mathrm{M} \\
180 \mathrm{M}\end{aligned}$ & $\frac{\$ 50 \mathrm{M}}{\overline{5} \mathrm{M}}$ \\
\hline Total & $\$ 779 \mathrm{M}$ & $\$ 55 \mathrm{M}$ \\
\hline
\end{tabular}

Production: The Note does not provide sufficient information to determine whether its comparison at the production stage is valid. It assumes that the capital required for a 60,000 unit assembler is one-fifth that required for the 300,000 unit producer ${ }^{60}$ Horvever, it seems equally plausible that economies of vertical integration and economies of scale in components production may allow the integrated producer to produce with less than five times the capital required by the assembler.

Distribution: The Note's treatment of distribution costs is clearly in error. It is unreasonable to suggest that an assembler can distribute 60,000 cars with no distribution costs whatsoever, while the integrated concern must spend $\$ 326$ million. The Note apparently does not in.

67. Id. at 588 .

68. Id. at 588-89 n.115.

69. Id. at 589 n.118. 
clude the capital the assembler requires for distribution because such capital comes from sources other than the assembler. However, under the dealer franchise system used by integrated firms today, independent businessmen provide the capital just as they would if distributors were legally independent of assemblers. The Note's source of information in fact recognized that capital is traditionally raised by independents. ${ }^{70}$ Thus, it is incorrect to include such costs as a capital requirement solely of the integrated firm.

Advertising: The Note assumes that the hypothetical assembler will require no more advertising dollars per car than the larger integrated producer. Yet economies of scale of advertisingi1 may well invalidate this assumption. It would appear that some fairly high absolute level of expenditures must be reached before a nationwide campaign becomes effective. This level of expenditures is not related directly to the volume of output but rather is related to contacts with consumers. Thus, the small assembler would probably have higher costs per car associated with advertising.

Tooling: The Note's analysis of tooling costs is inconsistent with its earlier argument. In discussing the "premature scrapping" of tools and dies, the Note states:

In 1923, it [GM] exhausted three full sets of dies and tools in producing a record 775,000 automobiles [point GM 1923 in Figure I]. Thus, it could replace the 1923 dies and tools with identical equipment or, at no extra cost, with dissimilar equipment. Consequently, GM changed the style characteristics of its 1924 models without increasing its costs .... . .2 $^{2}$

This implies that annual style change was not responsible for the capital required for retooling. Yet in discussing the added capital requirements necessitated by style change, the Note includes $\$ 180$ million, the total "tooling" costs of the integrated producer. The Note not only fails to explain this discrepancy, but is also misleading as to what the $\$ 180$ million of "retooling" includes. The Note's estimate of "retooling" expenditures,

was obtained by multiplying the per-unit full factor costs for style change (i.e., including the actual added production costs of producing the redesigned vehicle) as calculated at $\$ 600$ by Fisher,

70. AdMInistered Prices, supra note 11, at 16, cited in Note at $588 \mathbf{n . 1 1 5 .}$

71. See SCHERER, supra note 52, at 95-97.

72. Note at 581-82. 
Gryliches \& Kaysen, The Cost of Automobile Model Change During $A$ Decade, $70 \mathrm{~J}$. Pol. Econ. 433, 450 (1962), by the output $(300,000 \times \$ 600=\$ 180 \text { million. })^{73}$

As there is no explicit $\$ 600$ per car figure on the page cited, and it is difficult to know exactly what the Note means by "retooling" costs. At page 437 of the article cited, a figure of $\$ 584$ per car is given as reflecting some of the costs which Fisher attributes to style change. But this figure includes the costs of automatic transmission, power brakes, power steering, "extra" advertising, and the difference between the actual prices paid for cars and the price that would have been paid if consumers had purchased cars with 1949 specifications. It would seem that the "extra" advertising figure should have been included in the Note's estimate for advertising capital required. The rest of these factors should not be included in the costs of style change. ${ }^{74}$

The Note may also be in error in not including any capital requirement for the small firm in the tooling area. As mentioned earlier, the small firm must pay a price for components covering the tooling cost of its suppliers, even if it does not make the actual capital outlay for tooling. (In some instances, the components supplier may require that the purchaser of the components actually purchase the tooling.) ${ }^{76}$ The Note fails to capitalize these costs. It seems inconsistent for the Note to indicate that the dollar outlays needed to cover advertising expenditures constitute a capital requirement for the assembler, while the dollar outlays necessary to cover tooling costs are not a similar requirement.

In sum, it appears that the alleged differences in capital requirements between the assembler and the integrated producer can be attrib. uted to three things: The integrated producer is producing a larger volume of output than the assembler; is involved in more stages of production than the assembler; and has costs which have been capitalized and included as a "capital requirement," while the costs of the assembler have not been similarly capitalized. Thus, the $\$ 724$ million difference in capital requirements, assumed by the Note to be caused by style change, is attributable to other factors. The Note fails, therefore, to link annual style change to the "preservation" of concentration in the automobile industry. ${ }^{78}$

73. Id. at $588-89$ n.115.

74. WhITE, supra note 3, at 263.

75. See Alexander, Market Practices and Collective Bargaining in Automotive Parts, 69 J. Pol. ECON. 15, 15-16 (1961).

76. The Note also indicates that the "Kaiser-Frazier experience" shows how annual style change preserves concentration. Note at 586 . However, several factors were important 
III. Economic Performance and the Note's Proposed Remedies

After concluding its economic analysis of the automobile industry, the Note gives its legal argument for dissolution. Since our focus is on the economics of the Note, the rest of this comment will deal with economic performance and the Note's proposed remedies.

\section{A. The Note's Dissolution Remedy}

Noting that the Big Three in the automobile industry have fortyfive assembly plants, all of which have capacities of more than 60,000 units, the Note suggests that it would be desirable to make these separate, independent companies. The Big Three's parts and distribution facilities would also be made independent so that the new assembly firms would have a source of supply and method of distribution. The Note argues this solution would enable competitors to assemble automobiles with improved performance characteristics.

If only the assembly stage of production is considered, forty-five plant-firms could assemble cars in a reasonably efficient manner, since, in fact, there are forty-five plants doing that today. On the average, these plants could produce about 200,000 cars per year, for a total annual volume of nine million autos. The Note indicates, however, that under such an industry structure, "economists have estimated that more than 100 additional firms could enter and compete effectively in the automobile industry." 77 Yet none of the economists cited explicitly suggest this possibility. ${ }^{78}$ For a stable industry structure with a market demand of less than nine million United States-built units, the 145 firms would have to be limited to production of 60,000 units each. The forty-five existing firms would have substantially higher assembly costs than the new entrants, if they were forced by production regulations to produce only 60,000 units in plants designed to produce over 200,000.

Furthermore, economies of scale in advertising and components production may be sacrificed under the proposed industry structure, creating higher costs of assembled cars. The problem of efficient components production bears reemphasis. If an assembler produces cars which

in Kaiser-Frazier's failure, and there is no reason to single out style change. See Wurre, supra note 3, at 67-70; Kaiser-Frazier-The Roughest Thing IV'e Ever Tachled, FontuNe, July, 1951, at 161. The only other evidence the Note gives is estimates by potential entrants of the scale necessary for entry into the auto industry. Note at 590 . However, the Note fails to link annual style change with these estimates.

77. Note at 610 .

78. In fact, a careful reading of footnote 196 of the Note indicates that the Loescher and Schupach statements do not suggest such a possibility. 
require specialized components (i.e., components unique to that assembler), a 60,000 unit output will not be enough to achieve economies of scale at the components stage. If the assemblers independently purchase standard components, there may still be severe and recurring problems of coordination between the assembler and the components supplier. If the assemblers try to reduce these problems by coordination between themselves, it is questionable whether they could still be called "independent." And if an assembler tried to eliminate the problem via vertical integration, the Note's author would presumably disapprove.

The Note's suggestion to "spin-off" the distribution system, so as to open the system to all assemblers, is difficult to understand. Franchised dealers, in the industry today, provide their own capital and are free to sell cars made by several companies. According to Thomas Mann, over 3,000 of the Big Three's dealers carry vehicles not made by their principal supplier. ${ }^{70}$ If the Note's author wants each dealer to carry the cars of every manufacturer, each dealer could sell annually only about two cars produced by each manufacturer, since there are approximately 25,000 dealers. However, if each dealer is not required to sell cars produced by all manufacturers, it is unclear what mechanism will allocate makes between the various dealers.

The dealer's ability to serve the consumer also needs examination. While annual style change may have added to service problems, the lack of interchangeability of components is caused primarily by product differentiation between car makes. Eliminating or slowing style change would bring a decline in number of year-specific models a dealer must service, but the Note's proposal would increase the number of makes or brands which each dealer must service. The quality of service to the consumer may decline if dealers start carrying many different makes. If dealers carry only a few makes of cars, however, the dealer system would look very much as it does today.

The Note argues that under its proposed structure competition would increase the frequency of performance improvements. ${ }^{80}$ However, White indicates that

[t]he high visibility of automobiles, their importance as symbols in our society, their multi-faceted nature, all point toward the attractiveness of product behavior that stresses design change. Design change and efforts toward design distinctiveness also maintain and enlarge brand loyalty, reducing the price elasticity for each

79. Hearings on the Role of Giant Corporations Before the Subcomm. on Monopoly of the Senate Select Comm. on Small Business, 91st Cong., 1st Sess., pt. 1, at 86 (1969).

80. Note at 609 . 
company's own product. Further, these demand characteristics indicate that extensive advertising should appear worthwhile. They also provide incentives toward offering consumers a bigger and more luxurious product. On the other hand, consumers' lack of technical expertise should discourage product behavior that emphasized technological change. The fact that most technological changes are hidden beneath the sheet metal, where they cannot be easily displayed by proud owners, would also argue against this type of product behavior. ${ }^{81}$

Since these characteristics of automobile demand would appear to be unchanged by the Note's proposal, it seems likely that competition would continue to emphasize styling rather than technological change.

The short-term costs of the Note's dissolution program would be tremendously high, not only because breaking up the integrated firms into the number of units it suggests, in a manner ensuring survival of each unit, would be difficult, but also because the industry would incur costs in learning how to cope with the new business environment. It would take time for any viable components industry to evolve (even if the Big Three's parts facilities were spun-off), and during this time many of the assembly firms might run into insurmountable financial difficulties. When all these factors are added to the loss of efficiencies now flowing from integration, one must question whether the benefits of the solution really do outweigh its costs. The Note's indication that this solution might be politically infeasible is merely another way of saying that the government would-properly-hesitate to take the risks involved in such a drastic solution unless there were far greater certainty that alleged benefits would occur.

\section{B. The Moratorium Remedy}

The Note's alternative solution is a moratorium on annual style change (with "performance" modifications excepted), combined with supplemental relief, to encourage the development of independent components suppliers and distribution systems. The Note's author recognizes that such a moratorium alone would not have significant salutary effects on the performance of the automobile industry, but hopes that, in combination with the supplemental relief, it would help bring about a more open industry structure. New firms would enter an industry without style change and with "independent" components suppliers.

81. Whrre, supra note 3, at 104. 
The moratorium solution is questionable on two grounds. First, the length of the moratorium provides an interesting dilemma. If the Note's analysis of the disadvantages suffered by small firms because of premature scrapping is correct, then the moratorium should last long enough to allow the smallest "efficient" assembler to fully amortize its dies. This solution would, however, penalize other "efficient" assemblers which fully utilize their dies more quickly than the smallest efficient assembler. ${ }^{82}$ Furthermore, there is no economic rationale for the pace of style change to depend on the length of time it takes the smallest "efficient" firm in the industry to fully utilize its capital equipment. Each individual firm should evaluate style change in relation to its own demand and cost curves, and should change styles when the expected increase in revenues is greater than the expected increase in costs.

Second, the Note suggests that a moratorium might not effectively change industry structure, and that if it does not, dissolution may be necessary. It has been argued above that annual style change was not a primary cause of concentration in the automobile industry. If this is correct and a moratorium on style change would not affect the industry structure, dissolution would be mandatory. In effect, the Note is saying that it would demand dissolution even if its analysis were proven wrong by its suggested experiment.

\section{Summary and Conclusion}

The Note utilizes some faulty data, fails to examine certain factors lying behind its accurate data, and makes serious errors in interpretation. Its proposal contradicts its earlier analysis; it fails to explain or justify assumptions necessary to its argument. Finally, in some instances, sources cited actually contradict the Note's analysis.

The Note's proposed solution of breaking up the automobile industry would not remedy the alleged ills. In fact, there are good reasons to believe that such a fragmented industry would provide less desirable transportation to consumers, and at higher prices. It seems unwise to penalize the consumer in order to change the structure of an industry, when the proposed change appears to have little chance of providing any real benefits.

82. Assume an 80,000-unit-per-year firm facing a style change moratorium of four ycars and dies capable of producing 250,000 units. After $31 / 8$ years, the firm will have fully utilized its dies. If the moratorium is four years, the firm, to kecp producing, would have to replace its old dies with similar dies. If the firm then changed style at the four-ycar end, this replacement set of similar dies would be only $1 / 3$ utilized. This would give the firm higher costs. One alternative would be not to produce at all for $7 / 8$ of the ycar. Another would be not to change styles at the end of the fourth year, but to wait until $61 / 4$ years, when, if demand is maintained, the replacement dies will be fully utilized. 